\title{
Combining ability among apomictic and sexual parents of Urochloa humidicola
}

\author{
Ulisses José de Figueiredo ${ }^{1,2}$ (D) | Sanzio Carvalho Lima Barrios ${ }^{3}$ \\ Cacilda Borges do Valle ${ }^{3}$ (i) | José Airton Rodrigues Nunes ${ }^{1}$ (i)
}

\author{
${ }^{1}$ Department of Biology, Federal University \\ of Lavras, Lavras, Brazil \\ ${ }^{2}$ Barenbrug do Brasil Sementes Ltda, Guaíra, \\ Brazil \\ ${ }^{3}$ EMBRAPA Beef Cattle, Campo Grande, \\ Brazil

\section{Correspondence} \\ José Airton R. Nunes, Department of \\ Biology, Federal University of Lavras, P.O. \\ Box 3037, Lavras, Minas Gerais, ZIP Code \\ 37200-000, Brazil. \\ Email: jarnunes@ufla.br \\ Funding information \\ UNIPASTO; CNPq; Fundect and Embrapa \\ Beef Cattle; CAPES, Grant/Award Number: \\ 001
}

\begin{abstract}
The diallel cross constitutes an informative genetic design for choosing genitors and crosses in breeding programmes since it provides estimates of general (GCA) and specific (SCA) combining abilities. Because the breeding programme for Urochloa humidicola ([Rendle] Morrone \& Zuloaga; syn. Brachiaria humidicola [Rendle] Schweick) at Embrapa Beef Cattle is recent, these estimates are still unknown. Thus, the aim of this study was to obtain the estimates of GCA and SCA from the partial diallel cross design between sexual and apomictic parents. The crosses involved nine sexual and ten apomictic parents. Seventy-one full-sib progenies were obtained and evaluated in an incomplete block design, using all parents and the cv. BRS Tupi as a check. The agronomic and forage quality traits were evaluated using seven harvests. Statistical analysis was performed using the mixed model approach. Significant variations were associated with GCA among sexual parents for biomass yield and forage quality traits. However, this cannot be observed for apomictic parents for GCA. The SCA effect was not significant for the assessed traits. These results showed the predominance of additive effects. Sexual parents SEX3 and SEX4 presented the highest potential for contributing favourable alleles in hybrid combinations. The absence of GCA among apomictic parents and SCA suggests the need to increase genetic variability for the generation of breeding populations of $U$. humidicola.
\end{abstract}

\section{KEYWORDS}

apomixis, BLUP, Brachiaria humidicola, hybrid, partial diallel

\section{1 | INTRODUCTION}

The Brazilian livestock production is based on tropical cultivated pastures. The different production systems use mainly continuous stocking rate in extensive production systems using Urochloa cultivars. More intensive systems adopt rotational stocking rate using Megathyrsus maximus (B.K. Simon \& S.W.L. Jacobs) (syn. Panicum maximum Jacq.) cultivars in order to improve animal yield. Brazil has large extension of pasture areas with cultivated pastures occupying approximately 112 million of ha, while native pastures cover around $30 \%$ of the pasture areas (Instituto Brasileiro de Geografia e Estatística, 2017).

The Urochloa humidicola ([Rendle] Morrone \& Zuloaga; syn. Brachiaria humidicola [Rendle] Schweick) is a forage species used in some grass production systems due to its adaptation to acid soils and specially to the occurrence of waterlogging or flooding (KellerGrein et al., 1996). Initially, this species was used mostly in the Amazon region where rainfall is copious, but presently it is sowed all over tropical Brazil and in the Midwest region, mainly in the Pantanal biome, characterized by poorly drained soils (Santos et al., 2002). 
$U$. humidicola has mainly apomictic reproduction where the embryo is originated by parthenogenesis, and the fertilization occurs just for the endosperm formation by fusion of the reproductive nucleus of pollen and the polar nucleus of the megagametocyte. Thus, the apomictic plants are used only as male parents, as pollen donors, while the female plants have the normal megagametogenesis and can be crossed to produce hybrids.

Initially, the activities of breeding for this species were concentrated in the evaluation and mass selection of apomictic ecotypes from the germplasm bank of Embrapa Beef Cattle (Valle et al., 2008). A sexual ecotype was found in this bank $(\mathrm{H} 31)$ with the same ploidy level of some of the apomictic plants $(2 n=6 x=36)$. This sexual plant was crossed with the best apomictic genotype of the collection, cv. BRS Tupi, generating a population of approximately 360 hybrids. Figueiredo, Nunes, and Valle (2012) evaluated 50 of these hybrids for yield and forage quality traits for 2 years. The results showed there was genetic variation between the hybrids and the possibility of success with selection.

Figueiredo et al. (2012) also identified superior apomictic and sexual hybrids in relation to the parents, confirming the potential of these hybrids to become cultivars or superior parents in new crosses. This new scenario opened up the possibility to breed $U$. humidicola, mainly to generate populations and to apply new breeding methods, such as recurrent selection (Barrios, Valle, Alves, Simeão, \& Jank, 2013; Bernardo, 2010; Casler, 2010; Ramalho et al., 2012). The use of recurrent selection is reported in an interspecific sexual population of $U$. brizantha, $U$. decumbens and $U$. ruziziensis to improve the resistance to three species of Colombian spittlebugs [Aeneolamia varia (F.), A. reducta (Lallemand) and Zulia carbonaria (Lallemand)] (Miles et al., 2006). After six cycles, the authors observed decreasing of the survival rate of Aeneolamia varia nymphs to $87 \%$.

In the case of $U$. humidicola, the question arose to which genitor to select for the recombination and to form the base population for breeding. Breeders frequently use diallel in this situation, which allows for the exploitation of general (GCA) and specific (SCA) combining ability of parents (Griffing, 1956). There is no information on GCA and SCA for U. humidicola. There are some examples of diallel use in allopolyploids such as Urochloa spp. (Matias et al., 2018), wheat (Triticum aestivum L.; Gowda, Friedrich, Longin, Lein, \& Reif, 2012) and in autopolyploids such as alfalfa (Medicago sativa L.; Groose, Kojis, \& Bingham, 1988; Masood et al., 2014) and potato (Solanum tuberosum L.; Menezes, Pinto, \& Lambert, 2001). In the study of Matias et al. (2018) involving three species of Urochloa genus (U. ruziziensis (syn. Brachiaria ruziziensis), $U$. decumbens (syn. B. decumbens) and $U$. brizantha (B. brizantha)), they did not find a clear predominance of additive or dominance effects for agronomic and nutritional traits. Groose et al. (1988), considering the forage production, verified significant GCA for the tetraploid population, while the SCA was significant just at the diploid level. For allohexaploid wheat, the estimates of the GCA variances were more expressive than the SCA variances (Gowda et al., 2012). Nevertheless, studies about GCA and SCA are still lacking for U. humidicola (Jungmann et al., 2010; Vigna et al., 2016; Zorzatto et al., 2010).
Therefore, this study aimed to estimate GCA and SCA from a partial diallel cross design between apomictic and sexual parents of $U$. humidicola considering yield and forage quality traits.

\section{2 | MATERIALS AND METHODS}

The experiment was carried out in the Embrapa (Brazilian Agricultural Research Corporation) Beef Cattle which is located in Campo Grande-Mato Grosso do Sul state (latitude $20^{\circ} 27^{\prime}$ S, longitude $54^{\circ} 37^{\prime} \mathrm{W}$ and altitude of $530 \mathrm{~m}$ ). The average annual temperature is $23^{\circ} \mathrm{C}$. According to the Köppen classification, the climate is a tropical wet-dry subtype AW, characterized by a well-defined dry season in the colder and a rainy season in the warmer months. The soil type is an Alic Oxisol (EMBRAPA 1999).

The selection of 19 genitors, 10 apomictic and nine sexual was done after one and half year evaluation for yield and forage quality traits. The mode of reproduction of each genitor had been previously determined by cytological analyses of embryo sacs using interference contrast microscopy on methylsalicylate-cleared ovaries (Young et al. 1979). The crosses between the apomictic (male) and sexual (female) genitors followed the partial diallel design. We obtained 71 full-sib progenies with variable number of individuals or hybrids per each (Table 1 ).

There were evaluated 611 hybrids (non-replicated genotypes) of 71 progenies (Table 1), the ten apomictic parents, nine sexual parents and the cv. BRS Tupi (replicated genotypes). The experiment was planted using clonal sprigs on December 2012, and it was set up in an incomplete block design with 64 blocks of 15 plots each, totalizing 960 plots. Each plot after the establishment was $1.0 \mathrm{~m}^{2}$ with $1.2 \mathrm{~m}$ between rows.

A standardization cut was done on 03 November 2013. Additionally, seven consecutive cuts or harvests were done (04/24/2013, 07/15/2013, 10/14/2013, 12/02/2013, 01/30/2014, $03 / 28 / 2014$ and 05/21/2014). The cuts were done at $10 \mathrm{~cm}$ above the soil surface when the plants were at least $25 \mathrm{~cm}$ height.

The biomass yield traits measured were total fresh biomass yield (TFY, kg plot ${ }^{-1}$ ), total dry biomass yield (TDY, $\mathrm{kg} \mathrm{ha}^{-1}$ ), leaf percentage (\%L), leaf dry biomass yield (LDY, $\mathrm{kg} \mathrm{ha}^{-1}$ ) and regrowth capacity (REG). For forage quality, the crude protein (CP, \%), neutral detergent fibre (NDF, \%), in vitro organic matter digestibility (IVODM, \%) and lignin (LIG, \%) were estimated using the NIRS (near-infrared reflectance spectroscopy).

For TFY, TDY and REG, all seven harvests were considered, whereas for \%L, LDY and for quality forage traits, the data were measured just in the three first harvests. The statistical analyses were carried out considering the design structure and crosses scheme via mixed model approach of Henderson (Henderson, 1984; Möhring et al., 2011; Resende, 2002), following the statistical model:

$$
\begin{gathered}
y=X \beta+Z_{1} b+Z_{2} k+Z_{3} l+Z_{4} m+Z_{5} n+Z_{6} o+Z_{7} p+Z_{8} q+Z_{9} r \\
+Z_{10} s+Z_{11} t+Z_{12} u+Z_{13} v+e
\end{gathered}
$$


TAB LE 1 Number of individuals in the full-sib progenies obtained from the partial diallel between 10 apomictic and nine sexual parents of $U$. humidicola

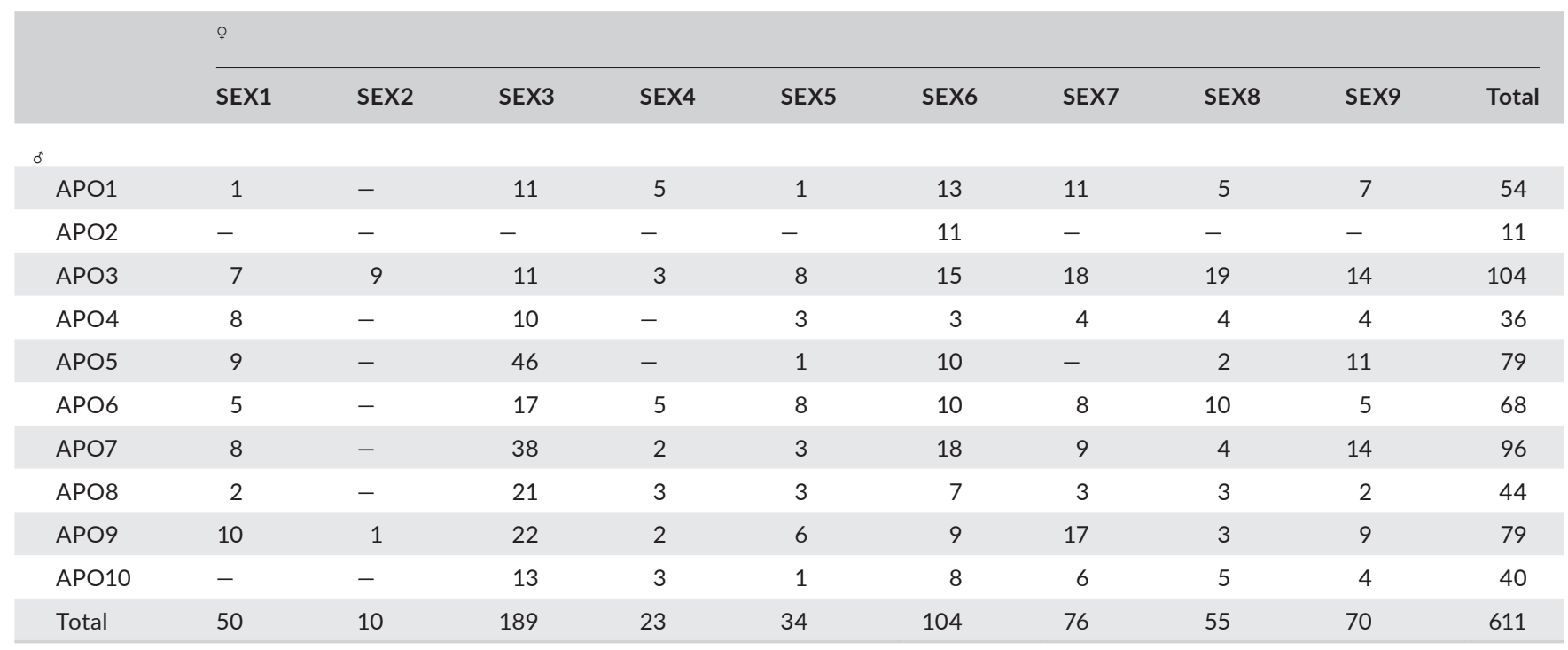

where $y$ : vector of phenotypic data; $X$ : incidence matrix for fixed effects; $Z$ : incidence matrix regarding the random effects; $\beta$ : vector of fixed effects of cut or harvest, genotype type (BRS Tupi, apomictic genitors (APO), sexual genitors (SEX) (Tupi + APO + SEX, (RG)) and non-repeated hybrid combination $(H))$ and harvest $\times$ genotype type interaction, added to the overall mean; $b$ : vector of block effects, where $b \sim \operatorname{NMV}\left(0, \sigma_{b}^{2}\right)$ and $\sigma_{b}^{2}$ is the variance component associated with the block effects; $k$ : vector of permanent environmental effects or plots, where $k \sim N M V\left(0, \sigma_{k}^{2}\right)$ and $\sigma_{k}^{2}$ is the variance associated with the plot effects; I: vector of the block $\times$ genotype effects interaction, where $1 \sim \operatorname{NMV}\left(0, \sigma_{1}^{2}\right)$ and $\sigma_{1}^{2}$ is the variance associated with the effects of the block $\times$ genotype interaction; $m$ : vector of sexual parents effects, where $m \sim \operatorname{NMV}\left(0, \sigma_{m}^{2}\right)$ and $\sigma_{m}^{2}$ is the variance associated with the sexual parents effects; $n$ : vector of apomictic parents effects, where $n \sim N M V\left(0, \sigma_{n}^{2}\right)$ and $\sigma_{n}^{2}$ is the variance associated with the apomictic parents effects; o: vector of GCA effects of sexual parents $\left(\mathrm{GCA}_{\text {sex }}\right)$, where $o \sim N M V\left(0, \sigma_{o}^{2}\right)$ and $\sigma_{o}^{2}$ is the variance

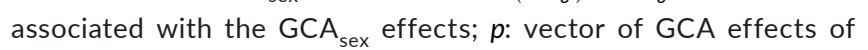
apomictic parents $\left(\mathrm{GCA}_{\mathrm{apo}}\right)$, where $p \sim \operatorname{NMV}\left(0, \sigma_{p}^{2}\right)$ and $\sigma_{p}^{2}$ is the

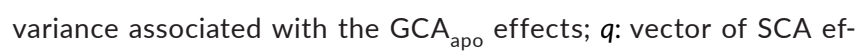
fects, where $q \sim \operatorname{NMV}\left(0, \sigma_{q}^{2}\right)$ and $\sigma_{q}^{2}$ is the variance associated with the SCA effects; $r$ : vector of effects of the sexual parents $\times$ harvests interaction, where $r \sim N M V\left(0, \sigma_{r}^{2}\right)$ and $\sigma_{r}^{2}$ is the variance associated with the effects of the sexual parents $\times$ harvests interaction; $s$ : vector of effects of the apomictic parents $\times$ harvests interaction, where $s \sim \operatorname{NMV}\left(0, \sigma_{s}^{2}\right)$ and $\sigma_{s}^{2}$ is the variance associated with the effects of the apomictic parents $\times$ harvests interaction; $t$ : vector of effects of the $\mathrm{GCA}_{\text {sex }} \times$ harvests effects interaction, where $t \sim \operatorname{NMV}\left(0, \sigma_{t}^{2}\right)$ and $\sigma_{t}^{2}$ is the variance associated with the effects of the $\mathrm{GCA}_{\text {sex }} \times$ harvests interaction; $u$ : vector of effects of the $\mathrm{GCA}_{\text {apo }} \times$ harvests interaction, where $u \sim \operatorname{NMV}\left(0, \sigma_{u}^{2}\right)$ and $\sigma_{u}^{2}$ is the variance associated with the effects of the $\mathrm{GCA}_{\text {apo }} \times$ harvests interaction; $v$ : vector of effects of the SCA $\times$ harvests interaction, where $v \sim \operatorname{NMV}\left(0, \sigma_{v}^{2}\right)$ and $\sigma_{v}^{2}$ is the variance associated with the effects of the SCA $\times$ harvests interaction and $e$ : vector of random errors, where $e \sim \operatorname{NMV}\left(0, \sigma_{e}^{2}\right)$ and $\sigma_{e}^{2}$ is the residual variance.

The variance components were estimated using the restricted maximum likelihood method, and the significance was assessed by likelihood ratio test (LRT). The predictions best linear unbiased prediction (BLUP) were obtained for the random effects, mainly per se and GCA effects for each genitor, and SCA. Furthermore, the broadsense heritability on the genotype mean basis was estimated using the following equation (Gowda et al., 2012):

$$
h^{2}=\frac{\left(\sigma_{o}^{2}+\sigma_{p}^{2}+\sigma_{q}^{2}\right)}{\left[\left(\sigma_{o}^{2}+\sigma_{p}^{2}+\sigma_{q}^{2}\right)+\left(\sigma_{t}^{2} / c\right)+\left(\sigma_{u}^{2} / c\right)+\left(\sigma_{v}^{2} / c\right)+\left(\sigma_{e}^{2} / c\right)\right]}
$$

where $c$ is the number of harvests. The standard error was estimated for each estimate of the $h^{2}$. Furthermore, the BLUPs of progenies or hybrids were predicted, such as the rank of 30 best hybrids and the genetic gain with selection for each trait. All the analyses were performed using the software ASReml 3.0 (Gilmour, Gogel, Cullis, \& Thompson, 2009).

\section{3 | RESULTS}

The genetic variance was significant $(p<.05)$ for the per se performance of apomictic $\left(\widehat{\sigma}_{m}^{2}\right)$ and sexual $\left(\hat{\sigma}_{n}^{2}\right)$ parents, considering most of traits, except to NDF and LIG (Sexual) and TFY, TDY and CP (Apomictic; Table 2). The sexual parents SEX4, SEX6 and SEX9 were most promising considering the biomass yield traits and digestibility. As for apomictic parents, the APO1 stood out with high LFY and IVDMO (Table 3).

Regarding the evaluation of the sexual and apomictic parents in hybrid combination, it was observed that only the sexual parents 
TAB LE 2 Estimates of the variance of sexual parents $\left(\sigma_{m}^{2}\right)$, variance of apomictic parents $\left(\sigma_{n}^{2}\right)$, variance of GCA sex $_{o}\left(\sigma_{o}^{2}\right)$, variance of GCA $\left(\sigma_{p}^{2}\right)$, variance of SCA $\left(\sigma_{q}^{2}\right)$, variance of sexual parents $\times$ harvests interaction $\left(\sigma_{r}^{2}\right)$, variance of apomictic parents $\times$ harvests interaction $\left(\sigma_{s}^{2}\right.$ ), variance of $\mathrm{GCA}_{\mathrm{sex}} \times$ harvests interaction $\left(\sigma_{t}^{2}\right)$, variance of $\mathrm{GCA}_{\mathrm{apo}} \times$ harvests interaction $\left(\sigma_{\mathrm{u}}^{2}\right)$, variance of SCA $\times$ harvests interaction $\left(\sigma_{v}^{2}\right)$, variance of residual errors $\left(\sigma_{e}^{2}\right)$, the broad-sense heritability on the genotype mean basis $\left(h^{2}\right.$, standard error between parenthesis), and overall mean $(\bar{y})$, of the mean of BRS Tupi cultivar $\left(\bar{y}_{\text {BRSTupi }}\right)$ and the mean of 611 hybrids $\left(\bar{y}_{\text {Hybrids }}\right)$ for the biomass yield and forage quality traits of the evaluation of full-sib progenies of $U$. humidicola for seven harvests

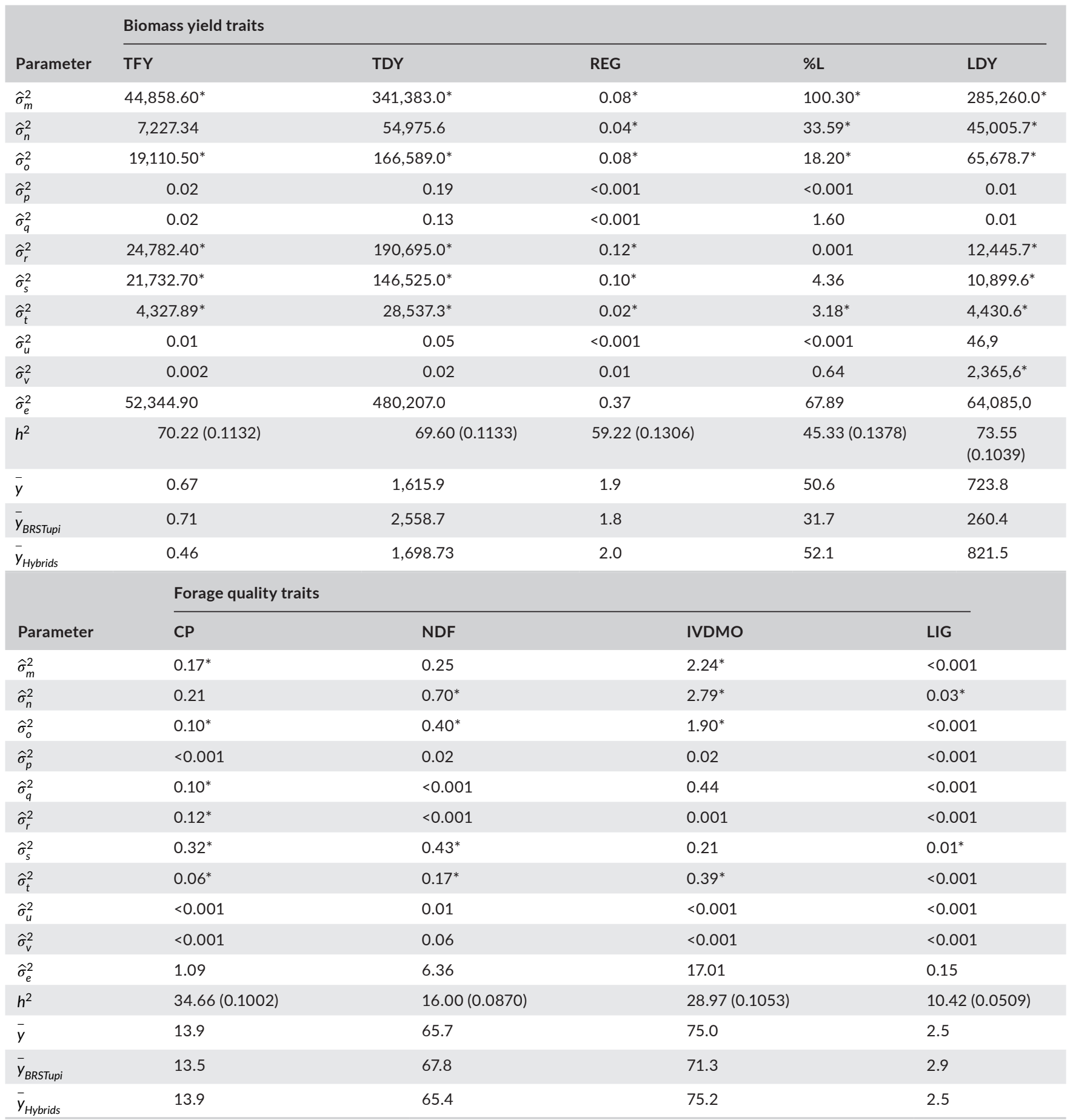

Note: TFY, total fresh biomass yield ( $\left.\mathrm{kg} \mathrm{plot}^{-1}\right)$; TDY, total dry biomass yield $\left(\mathrm{kg} \mathrm{ha}^{-1}\right)$; \% , leaf percentage (\%); LDY, leaf dry biomass yield (kg ha ${ }^{-1}$ ); REG, regrowth capacity; CP, crude protein (\%); NDF, neutral detergent fibre (\%); IVDMO, in vitro digestibility of organic matter (\%) and LIG, lignin (\%). *Significant by the LRT.

showed significant GCA for most traits, except for LIG (Table 2). The parent SEX3 was the best parent considering the GCA for TDY, LDY and REG, followed by SEX4 for TDY and LDY. For \%L, the parents with biggest GCA predictions were SEX4 and SEX9 (Table 4). The sexual parents that showed the best performance per se (Table 3) were not the best in GCAs estimates (Table 4), except for \%L, where 


\begin{tabular}{|c|c|c|c|c|c|c|c|c|c|}
\hline Parent & TFY & TDY & REG & $\% L$ & LDY & $\mathrm{CP}$ & NDF & IVDMO & LIG \\
\hline SEX1 & 0.67 & $2,042.0$ & 2.3 & 39.2 & 575.2 & 14.4 & 65.9 & 74.7 & 2.7 \\
\hline SEX2 & 0.46 & $1,557.3$ & 2.1 & 40.7 & 488.2 & 13.8 & 66.2 & 75.7 & 2.7 \\
\hline SEX3 & 0.62 & $1,975.6$ & 2.1 & 40.0 & 588.0 & 14.2 & 66.1 & 74.5 & 2.7 \\
\hline SEX4 & 0.72 & $2,183.4$ & 2.4 & 52.2 & 895.2 & 14.3 & 65.7 & 77.0 & 2.7 \\
\hline SEX5 & 0.42 & $1,357.9$ & 1.9 & 39.4 & 378.7 & 14.4 & 66.1 & 76.6 & 2.7 \\
\hline SEX6 & 0.81 & $2,494.5$ & 2.2 & 50.1 & $1,070.6$ & 14.4 & 65.4 & 77.4 & 2.7 \\
\hline SEX7 & 0.52 & $1,683.9$ & 2.1 & 44.3 & 504.3 & 13.9 & 66.4 & 75.0 & 2.7 \\
\hline SEX8 & 0.51 & $1,678.2$ & 2.0 & 36.9 & 482.4 & 14.1 & 66.2 & 74.8 & 2.7 \\
\hline SEX9 & 0.10 & $3,128.3$ & 2.7 & 67.7 & $2,043.7$ & 13.4 & 65.3 & 78.1 & 2.7 \\
\hline $\bar{y}_{\text {Sex }}$ & 0.64 & $2,011.3$ & 2.2 & 45.6 & 780.7 & 14.1 & 65.9 & 76.0 & 2.7 \\
\hline APO1 & 0.76 & $2,332.0$ & 2.1 & 46.0 & 787.6 & 14.4 & 65.3 & 77.1 & 2.6 \\
\hline APO2 & 0.77 & $2,392.2$ & 2.5 & 60.2 & $1,166.3$ & 13.9 & 66.1 & 74.3 & 2.7 \\
\hline $\mathrm{APO} 3$ & 0.70 & $2,194.5$ & 2.2 & 48.3 & 756.3 & 14.3 & 65.8 & 76.6 & 2.6 \\
\hline APO4 & 0.61 & $1,877.4$ & 2.0 & 43.4 & 538.9 & 14.4 & 65.9 & 74.7 & 2.9 \\
\hline APO5 & 0.69 & $2,195.3$ & 2.1 & 40.9 & 639.2 & 14.3 & 66.9 & 72.6 & 2.7 \\
\hline APO6 & 0.71 & $2,206.2$ & 2.2 & 47.5 & 881.9 & 14.7 & 65.3 & 76.3 & 2.5 \\
\hline APO7 & 0.82 & $2,477.6$ & 2.4 & 47.0 & 707.8 & 14.7 & 66.2 & 74.6 & 2.8 \\
\hline APO8 & 0.73 & $2,209.2$ & 2.2 & 43.5 & 714.7 & 14.6 & 65.2 & 76.0 & 2.9 \\
\hline APO9 & 0.70 & 2,197.7 & 2.2 & 44.6 & 735.3 & 14.2 & 65.5 & 77.2 & 2.9 \\
\hline APO10 & 0.65 & $2,016.1$ & 2.2 & 43.7 & 490.8 & 15.1 & 64.4 & 76.8 & 2.6 \\
\hline $\bar{y}_{\mathrm{Apo}}$ & 0.72 & $2,209.8$ & 2.2 & 46.5 & 741.9 & 14.4 & 65.7 & 75.6 & 2.7 \\
\hline
\end{tabular}

TABLE 3 BLUP-mean estimates of sexual and apomictic parents per se performance for the biomass yield and forage quality traits, in the evaluation of full-sib progenies of $U$. humidicola

Note: TFY, total fresh biomass yield $\left(\mathrm{kg} \mathrm{plot}^{-1}\right)$; TDY, total dry biomass yield $\left(\mathrm{kg} \mathrm{ha}^{-1}\right)$; \% $\%$, leaf percentage (\%); LDY, leaf dry biomass yield ( $\mathrm{kg} \mathrm{ha}^{-1}$ ); REG, regrowth capacity; CP, crude protein (\%); NDF neutral detergent fibre (\%); IVDMO, in vitro digestibility of organic matter (\%) and LIG, lignin (\%).

the behaviour was coincident. Regarding the forage quality traits SEX 3 and SEX4 parents were the best, reinforcing the fact that these are most promising, both for biomass yield and forage quality traits.

The SCA was not detected, with exception for CP (Table 2). Based on estimates of the SCA for $\mathrm{CP}$, there was a greater magnitude of this effect for SEX6 $\times$ APO2, SEX7 × APO8, SEX6 × APO9 and SEX9 $\times$ APO10 crossings (data not shown). However, the sexual parents in these combinations have not expressed high GCA.

There was a differential response of the per se parents across harvests $(p<.05)$, except for \%L, NDF, IVDMO and LIG for the sexual parents, and \%L and IVDMO for apomictic parents. The $\mathrm{GCA}_{\text {sex }} \times$ harvest interaction was also significant $(p<.05)$ for most traits with exception of LIG. For GCA apo $\times$ harvest and SCA $\times$ harvest, interactions were not significant for the traits ( $p>.05)$, except for the SCA $\times$ harvest for $\% \mathrm{~L}$ and LDY (Table 2). The presence of genotype by harvest interaction is common for forage species (Assis, Santos, Flores, \& Valle, 2014; Figueiredo, Nunes, Valle, Barrios, \& Alves, 2013; Souza Sobrinho et al., 2010) since there is seasonality of growth in perennial forages. It is worth to highlight that the inference about the GCA and SCA was done based on the average over harvests. Thus, these combining ability effects and their variances were estimated free of the genotype by harvest effect.

The broad-sense heritabilities on the genotype mean basis $\left(h^{2}\right.$ ) were $70.22 \%$ (TFY), 69.60\% (TDY), 59.22\% (REG), 45.33\% (\%L) and 73.55\% (LDY; Table 2). Whereas, for the forage quality traits, the magnitude of the $h^{2}$ was lower, ranging from $10.42 \%$ (LIG) to $34.66 \%$ (CP) (Table 2). These values of $h^{2}$ and their standard errors indicated a good reliability for genotypic selection, mainly for biomass yield traits. Similar results have been reported to $U$. humidicola (Assis et al., 2014; Figueiredo et al., 2012).

The genetic gains with selection of the best top 30 hybrids for yield traits were above $17 \%$, highlighting the gain reached to LDY $(127.9 \%)$. For the forage quality traits, the genetic gains were lower: 6.4\% (CP), 2.1\% (NDF), 3.2\% (IVDMO) and 5.1\% (LIG; Figure 1). It was also found that all the top 30 hybrids for the biomass yield traits came from crosses with SEX3 parent.

\section{4 | DISCUSSION}

The genetic breeding of $U$. humidicola is a recent activity (Jank et al., 2011). The crossings started in 2005 , after the identification of an unique allohexaploid sexual plant in the germplasm bank (Jungmann et al., 2010). The first cross was done with the apomictic cultivar BRS Tupi, and generating superior sexual and apomictic hybrids for biomass yield and forage quality traits (Figueiredo et al., 2012). Complementing these evaluations, the characterization of the best genotypes in crossings is important for the continuity of the breeding programme, 
TAB LE 4 Estimates of general combining ability for the sexual parents and standard errors (SE) considering the traits total fresh biomass yield (TFY, kg plot ${ }^{-1}$ ), total dry biomass yield (TDY, $\mathrm{kg} \mathrm{ha}^{-1}$ ), regrowth capacity (REG), leaf percentage (\%L, \%), leaf dry biomass yield (LDY, $\mathrm{kg} \mathrm{ha}^{-1}$ ), regrowth capacity (REG), crude protein (CP, \%), neutral detergent fibre (NDF, \%), in vitro digestibility of organic matter (IVDMO, \%) and lignin (LIG, \%), in the evaluation of full-sib progenies of U. humidicola

\begin{tabular}{|c|c|c|c|c|c|c|c|c|c|c|}
\hline Parent & TFY & $S E$ & TDY & $S E$ & REG & SE & $\% \mathrm{~L}$ & $S E$ & LDY & SE \\
\hline SEX2 & -78.04 & 75.83 & -252.20 & 218.00 & -0.05 & 0.16 & 0.38 & 2.77 & -107.80 & 133.30 \\
\hline SEX4 & 0.50 & 64.93 & 14.21 & 186.50 & -0.05 & 0.13 & 4.88 & 2.31 & 85.22 & 114.10 \\
\hline SEX5 & -27.62 & 61.55 & -83.27 & 176.90 & -0.03 & 0.13 & -0.29 & 2.18 & -28.34 & 108.80 \\
\hline SEX7 & -27.34 & 56.89 & -71.22 & 163.70 & 0.06 & 0.12 & 0.78 & 2.00 & -31.28 & 101.50 \\
\hline SEX8 & -124.00 & 58.36 & -356.50 & 167.90 & -0.33 & 0.12 & -4.92 & 2.07 & -267.40 & 104.20 \\
\hline SEX9 & -18.87 & 57.22 & -56.12 & 164.60 & -0.04 & 0.12 & 3.48 & 2.01 & -16.74 & 102.20 \\
\hline Parent & \multicolumn{2}{|c|}{$\mathrm{CP}$} & $S E$ & NDF & SE & & IVDMO & SE & LIG & $S E$ \\
\hline SEX4 & \multicolumn{2}{|c|}{-0.11} & 0.23 & -0.55 & 0.40 & & 1.82 & 0.77 & -0.020 & 0.032 \\
\hline SEX5 & \multicolumn{2}{|c|}{0.13} & 0.22 & -0.21 & 0.38 & & 0.56 & 0.73 & -0.004 & 0.031 \\
\hline SEX6 & \multicolumn{2}{|c|}{0.16} & 0.20 & -0.20 & 0.34 & & 0.49 & 0.66 & 0.026 & 0.027 \\
\hline SEX7 & \multicolumn{2}{|c|}{-0.18} & 0.20 & 0.00 & 0.34 & & 0.29 & 0.68 & 0.004 & 0.029 \\
\hline SEX8 & \multicolumn{2}{|c|}{-0.22} & 0.21 & 0.84 & 0.36 & & -1.49 & 0.70 & -0.002 & 0.030 \\
\hline SEX9 & \multicolumn{2}{|c|}{-0.20} & 0.20 & 0.46 & 0.35 & & -0.30 & 0.68 & -0.001 & 0.029 \\
\hline
\end{tabular}

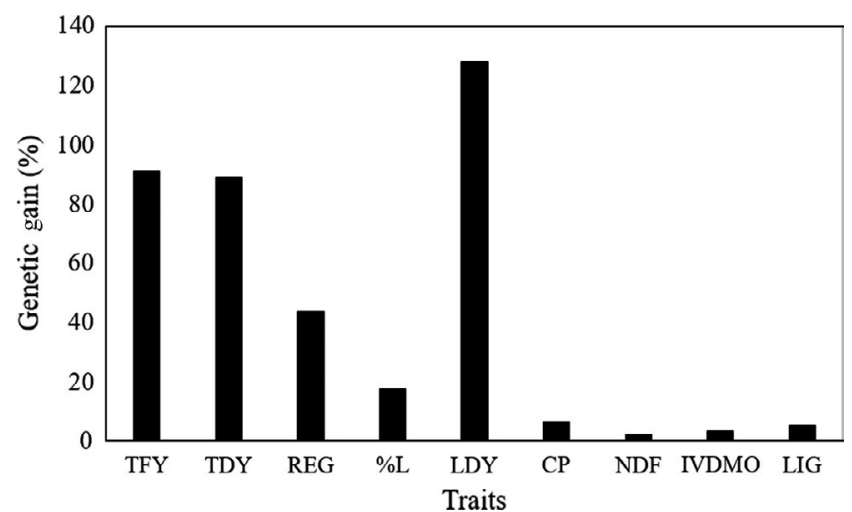

FIGURE 1 Estimates of the genetic gain (\%) with selection of the best top 30 hybrids for the traits total fresh biomass yield (TFY, $\mathrm{kg} \mathrm{plot}^{-1}$ ), total dry biomass yield (TDY, kg ha ${ }^{-1}$ ), leaf percentage (\%L, \%), leaf dry biomass yield (LDY, $\mathrm{kg} \mathrm{ha}^{-1}$ ), regrowth capacity (REG), crude protein (CP, \%), neutral detergent fibre (NDF, \%), in vitro digestibility of organic matter (IVDMO, \%) and lignin (LIG, \%) of U. humidicola

especially in the selection of the parents. For this, the main strategy used by breeders is the diallel design. This scheme of crosses allows for the estimation of combining ability of genotypes and, furthermore, to estimate genetic parameters from the evaluation of progenies.

A relevant question to get reliable variance estimates of GCA and SCA is the representativeness of the parents in the crosses. In general, the condition of this work was favourable to estimate the GCA per parent, since for almost all parents the number of crossings per parent were at least three (Veiga et al., 2000), excepting for parents SEX2 and APO2 (Table 1). Nevertheless, just the sexual parents showed variation in GCA. The apomictic parents did not show significant GCA variance, and the SCA was not significant between the combinations of sexual or apomictic parents for the evaluated traits (Table 2). This scenario shows the predominance of variance caused by additive effects in the absence of epitasis (Falconer and Mackay, 1996; Ramalho et al., 2012). In a diallel with Urochloa species (U. ruziziensis, $U$. decumbens and U. brizantha), the predominance of additive or dominance effects changed regarding agronomic and nutritional trait assessed (Matias et al. 2018). The traits density of regrown tillers, regrowth speed, LDM, CP, NDF and IVDMO were predominantly additive, with proportions varying from $20 \%$ to $90 \%$, whereas LIG showed only dominance effect of $53 \%$.

For apomictic parents, even considering the lack of per se variability for some traits (TFY, TDY and CP), a significant GCA apo $_{\text {os }}$ expected for these traits, since the genotypes are allohexaploids (Boldrini, Micheletti, et al., 2009a; Boldrini, Pagliarini, \& Valle, 2009b; Jungmann et al., 2010; Vigna et al., 2016) and there is plenty of variability within the population (Figueiredo et al., 2012). Furthermore, according to the literature, allopolyploids are expected to be less affected by inbreeding depression than autopolyploid or diploid species (Comai, 2005; Husband et al., 2008). 
Nevertheless, the presence or absence of GCA should be not ignored, even for traits where the per se effect was not present. The genotypic value $\left(G_{i j}\right)$ of each diploid individual considering a loci $A$, with alleles $A_{i}$ and $A_{j}$, is defined as $G_{i j}=\mu+\alpha_{i}+\alpha_{j}+\delta_{i j}$, where $\mu$ is the population mean, $\alpha_{i}$ is the average effect of allele $A_{i}, \alpha_{j}$ is the average effect of allele $A_{j}$ and $\delta_{i j}$ is the dominance deviation associated to interaction between alleles $A_{i}$ and $A_{j}$. The GCA estimate is obtained by the expression of $\mathrm{P} 1$ when crossed with a tester $\mathrm{P} 2\left(G_{\mathrm{P}^{1} \mathrm{j}^{\mathrm{P} 2}}\right)$, where $\mathrm{P} 1$ or $\mathrm{P} 2$ indicate the original alleles. Thus, $G_{i^{P 1} j^{P 2}}=\mu_{P 1 \times P 2}+\alpha_{i}^{P 1}+\alpha_{j}^{P 2}+\delta_{i j}^{P 1 P 2}$, where $\mu_{P 1 \times P 2}$ is the mean of crossings between two populations, $\alpha_{i}^{P 1}$ is average effect of allele $A_{i}^{P 1}$ when is tested with the P2, $\alpha_{j}^{P 2}$ is average effect of allele $A_{j}^{P 2}$ when is tested with the P2 and $\delta_{i j}^{P 1 P 2}$ is the dominance deviation associated with genotype $A_{i}^{P 1} A_{j}^{P 2}$ (Bernardo, 2010). From these inferences, it is possible to observe that $G_{i j}$ is dependent on the average effect of the alleles within the same population, whereas the estimate of $G_{i p_{1} j_{2}}$ the cross $\mathrm{P} 1 \times \mathrm{P} 2$ is the reference population.

Thus, the association between $G_{i j}$ and $G_{i p_{1 j} p_{2}}$ is not expected, and in others words, the lack of variation in the performance per se will not interfere in the null GCA and SCA estimates, nor in the lack of association between the BLUPs of parents and the respective GCA estimates, considering diploid species. In this case, within a hexaploid species such as $B$. humidicola, the hybrids could range from being nuliplex (aaaaaa) to hexaplex (AAAAAA), and this allelic interactions could range from a biallelic to a hexallelic one, which could increase the lack of association between the $G_{i j}$ and $G_{i p 1 j p 2}$.

Another hypothesis is the fact of apomictic genotypes having the same gamete constitution, apomixis functioning as a genetic block suffering no alteration over the meiosis, thus, there is the possibility of lack of recombination in the formation of gametes. An example was reported in males of Drosophila melanogaster, where the crossing over and the recombination frequency appeared just in the females, with low frequencies in the male (Hiraizumi, 1971).

On the other side, if the parents are not representative of the population, the estimate could be biased, considering the evaluation of endogamic lines or populations without Hardy-Weinberg equilibrium (Griffing, 1956). However, in this study, the sexual parents are in heterozygosis and, furthermore, they are hexaploid individuals, where the probability of an identical allele being identical in the offspring is much lower than in diploids species (Wricke and Weber, 1986). Thus, endogamy should not be present.

The significant effect of variance of GCA $_{\text {sex }}$ allowed to select parents for the increase of frequency of favourable alleles in future offspring, considering FTY, TDY and LDY. The best hybrid with higher GCA estimate was SEX3 which also presented lower standard error than the other sexual hybrids. SEX3 hybrid was also the hybrid with the highest number of offspring (189). On the other extreme, just 11 offspring came from SEX2, resulting in low precision in the GCA estimative.

For \%L, the hybrids SEX4 and SEX9 were superior. This character is very important for the breeding programme of $U$. humidicola, because the ruminant animals select the leaf during grazing due to its higher nutritional value (Trindade et al., 2007). SEX4 parent was superior in relation to the other sexual parents, considering GCA for TFY, TDY and \%L, therefore this parent can contribute in crosses to improve these traits.

The choice of a diallel model, considering the statistical overview, might interfere in the parameter estimates (Yao et al., 2013). In the present study, the estimates of GCA and SCA variances were done considering the method 4 of Griffing (Möhring et al., 2011), where in the estimation of combining abilities, the per se performance of the parents was not considered directly. Yao et al. (2013) reported that method 4 of Griffing produced estimates of SCA equal to methods II and III of Gardner e Eberhart. In this study, the SCA variance was significant just for $\mathrm{CP}$, thus the possibility to find superior hybrids combination is low. Despite the absence of SCA, it was possible to observe variability for the considered traits between the hybrids generated. This fact is important for the continuity of the programme aiming at the selection of potential candidates for cultivars or parents.

This study proposed to select sexual and apomictic parents to subsidize the composition of a breeding base population in the recurrent selection programme and thus contribute to increasing the diversification of pastures with this species in Brazil. However, the results suggest caution, especially in relation to apomictic genotypes, limiting decisions about future crossings. Apomictic genotypes are used as male parents, but the presence of GCA just within the sexual genotypes, indicates that the programme should be based on improving sexual population, thus exploiting the additive effects present.

Improving the apomictic population can be impaired due to non-presence of GCA among the apomictic parent, compromising the potential to obtaining future candidates. Thus, studies in relation to endogamy are pertinent for better understanding the lack of SCA within this population. Thus, an important recommendation to the $U$. humidicola breeding programme is the inclusion in future crosses of a new source of variability (non-related apomictic parents to BRS Tupi). Nevertheless, superior hybrids have been found in the generated population relative to BRS Tupi progenitor for all traits, mainly for \%L, LDY, CP, IVDMO and LIG, and additionally expressive selection gain was observed for biomass yield traits.

\section{5 | CONCLUSION}

GCA was predominant for biomass yield and forage quality traits from the partial diallel cross design between apomictic and sexual parents of $U$. humidicola evaluated. Nevertheless, significant GCA variation was only observed for sexual parents, while the apomictic parents did not differ in relation to GCA effect. The SEX3 parent presented high GCA for all traits, among the sexual parents.

\section{ACKNOWLEDGMENTS}

The authors thank to UNIPASTO, CNPq, Fundect and Embrapa Beef Cattle for the financial support to carry out the experiments and to 
CAPES for granting a Doctorate's degree scholarship (Finance code 001).

\section{ORCID}

Ulisses Figueiredo (iD https://orcid.org/0000-0002-9207-0254

Sanzio Barrios (iD https://orcid.org/0000-0002-5490-4959

Cacilda Valle (iD https://orcid.org/0000-0003-3054-5127

José Nunes iD https://orcid.org/0000-0002-6260-7890

\section{REFERENCES}

Barrios, S. C. L., Valle, C. B., Alves, G. F., Simeão, R. M., \& Jank, L. (2013). Reciprocal recurrent selection in the breeding of Brachiaria decumbens. Tropical Grasslands, 1, 52-54. https://doi.org/10.17138/ TGFT(1)52-54

Bernardo, R. (2010). Breeding for quantitative traits in plants. Woodbury, NY: Stemma.

Boldrini, K. R., Micheletti, P. L., Gallo, P. H., Mendes-Bonato, A. B., Pagliarini, M. S., \& Valle, C. B. (2009a). Origin of a polyploid accession of Brachiaria humidicola (Poaceae: Panicoideae: Paniceae). Genetics and Molecular Research, 8, 888-895. https://doi.org/10.4238/ vol8-3gmr617

Boldrini, K. R., Pagliarini, M. S., \& Valle, C. B. (2009b). Meiotic behavior of a nonaploid accession endorses $\mathrm{x}=6$ for Brachiaria humidicola (Poaceae). Genetics and Molecular Research, 8, 1444-1450. https:// doi.org/10.4238/vol8-4gmr679

Casler, M. D. (2010). Changes in mean and genetic variance during two cycles of within-family selection in Switchgrass. BioEnergy Research, 3, 47-54. https://doi.org/10.1007/s12155-009-9071-9

Comai, L. (2005). The advantages and disadvantages of being polyploid. Nature Reviews Genetics, 6, 836-846. https://doi.org/10.1038/ nrg1711

de Assis, G. M. L., dos Santos, C. F., Flores, P. S., \& Valle, C. B. (2014). Genetic divergence among Brachiaria humidicola (Rendle) Schweick hybrids evaluated in the Western Brazilian Amazon. Crop Breeding and Applied Biotechnology, 14, 224-231.

de Menezes, C. B., Pinto, C. A. B. P., \& Lambert, E. S. (2001). Combining ability of potato genotypes for cool and warm seasons in Brazil. Cropp Breeding and Applied Biotechnology, 1, 145-157. https://doi. org/10.13082/1984-7033.v01n02a06

de Resende, M. D. V. (2002). Genética biométrica e estatística: No melhoramento de plantas perenes. Brasília: EMBRAPA Informação Tecnológica.

Empresa Brasileira de Pesquisa Agropecuária-EMBRAPA. (1999). Sistema brasileiro de classificação de solos. Brasília: EMBRAPA.

Falconer, D. S., \& Mackay, T. F. C. (1996). Introduction to quantitative genetics. London, UK: Longman Malaysia.

Figueiredo, U. J., Nunes, J. A. R., \& Valle, C. B. (2012). Estimation of genetic parameters and selection of Brachiaria humidicola progenies using a selection index. Crop Breeding and Applied Biotechnology, 12, 237-244. https://doi.org/10.1590/S1984-70332012000400002

Figueiredo, U. J., Nunes, J. A. R., Valle, C. B., Barrios, S. C. L., \& Alves, G. F. (2013). Effects of season and year of evaluation in the selection of Brachiaria humidicola hybrids. Tropical Grasslands, 1, 76-77. https:// doi.org/10.17138/TGFT(1)76-77

Gilmour, A., Gogel, B. J., Cullis, B. R., \& Thompson, R. (2009). ASReml user guide, release 3.0. Hemel Hempstead: UK International Ltd.

Gowda, M., Friedrich, C., Longin, H., Lein, V., \& Reif, J. C. (2012). Relevance of specific versus general combining ability in winter wheat. Crop Science, 52, 2494-2500. https://doi.org/10.2135/crops ci2012.04.0245

Griffing, B. (1956). A generalised treatment of the use of diallel crosses in quantitative inheritance. Heredity, 10, 31-50. https://doi. org/10.1038/hdy.1956.2

Groose, R. W., Kojis, W. P., \& Bingham, E. T. (1988). Combining ability differences between isogenic diploid and tetraploid alfalfa. Crop Science, 28, 7-10. https://doi.org/10.2135/cropsci1988.00111 83X002800010002x

Henderson, C. R. (1984). Applications of linear models in animal breeding. Guelph, ON: University of Guelph.

Hiraizumi, Y. (1971). Spontaneous recombination in Drosophila melanogaster males. Proceedings of the National Academy of Sciences, 68, 268-270. https://doi.org/10.1073/pnas.68.2.268

Husband, B. C., Ozimec, B., Martin, S. L., \& Pollock, L. (2008). Mating consequences of polyploid evolution in flowering plants: Current trends and insights from synthetic polyploids. International Journal of Plant Sciences, 169, 195-206. https://doi.org/10.1086/523367

Instituto Brasileiro de Geografia e Estatística. (2017). Censo agropecuário 2017: Resultados preliminares. ISSN: 01036157. Rio De Janeiro, 2017.

Jank, L., Valle, C. B., \& Resende, R. M. S. (2011). Breeding tropical forages. Crop Breeding and Applied Biotechnology, 11, 27-34. https://doi. org/10.1590/S1984-70332011000500005

Jungmann, L., Vigna, B. B., Boldrini, K. R., Sousa, A. C., Valle, C. B., Resende, R. M., ... de Souza, A. P. (2010). Genetic diversity and population structure analysis of the tropical pasture grass Brachiaria humidicola based on microsatellites, cytogenetics, morphological traits, and geographical origin. Genome, 53, 698-709.

Keller-Grein, G., Maass, B. L., \& Hanson, J. (1996). Natural variation in Brachiaria and existing germplasm collections. In J. W. Miles, B. L. Maass, \& C. B. Valle (Eds.), Brachiaria: Biology, agronomy and improvement (pp. 17-42). Colombia: Cati.

Masood, S. A., Ahmad, S., Kashif, M., \& Ali, Q. (2014). Role of combining ability to develop higher yielding wheat (Triticum aestivum L.) genotypes: An overview. Natural Sciences, 12, 155-161.

Matias, F. I., Barrios, S. C. L., Bearari, L. M., Meireles, K. G. X., Mateus, R. G., Amaral, P. N. C., ... Fritsche-Neto, R. (2018). Contribution of additive and dominance effects on agronomical and nutritional traits, and multivariate selection on Urochloa spp. Hybrids Crop Science, 58, 1-15.

Miles, J. W., Cardona, C., \& Sotelo, G. (2006). Recurrent selection in a synthetic brachiariagrass population improves resistance to three spittlebug species. Crop Science, 46, 1088-1093. https://doi. org/10.2135/cropsci2005.06-0101

Möhring, J., Melchinger, A. E., \& Piepho, H. P. (2011). REML-based diallel analysis. Crop Science, 51, 470-478. https://doi.org/10.2135/crops ci2010.05.0272

Ramalho, M. A. P., Abreu, A. F. B., dos Santos, J. B., \& Nunes, J. A. R. (2012). Aplicações da genética quantitativa no melhoramento de plantas autógamas. Lavras: Editora UFLA

Santos, S. A., Pellegrin, A. O., Moraes, A. S., Barros, A. T. M., Comastri Filho, J. A., Sereno, J. R. B., ... Abreu, U. G. P. (2002). Sistema de produção de gado de corte do Pantanal. Corumbá: EMBRAPA Pantanal.

Souza Sobrinho, F., Borges, V., Ledo, F. J. S., \& Kopp, M. M. (2010). Repetibilidade de características agronômicas e número de cortes necessários para seleção de Urochloa ruziziensis. Pesquisa Agropecuária Brasileira, 45, 579-584. https://doi.org/10.1590/ S0100-204X2010000600007

Trindade, J. K., Silva, S. C., de Souza Júnior, S. J., Giacomini, A. A., Zeferino, C. V., Guarda, V. D. A., \& Carvalho, P. C. F. (2007). Composição morfológica da forragem consumida por bovinos de corte durante o rebaixamento do capim-marandu submetido a estratégias de pastejo rotativo. Pesquisa Agropecuária Brasileira, 42, 883-890. https://doi. org/10.1590/S0100-204X2007000600016 
Valle, C. B., Simioni, C., Resende, R. M. S., Jank, L., \& Chiari, L. (2008). Melhoramento genético de Brachiaria. In R. M. S. Resende, C. B. Valle, \& L. Jank (org.), Melhoramento de Forrageiras Tropicais (pp. 1353). Campo Grande: EMBRAPA Gado de Corte.

Veiga, R. D., Ferreira, D. F., \& Ramalho, M. A. P. (2000). Eficiência dos dialelos circulantes na escolha de genitores. Pesquisa Agropecuária Brasileira, 35, 1395-1406. https://doi.org/10.1590/S0100-204X2000000700014

Vigna, B. B. Z., Oliveira, F. A., Toledo-Silva, G., Silva, C. C., Valle, C. B., \& Souza, A. P. (2016). Leaf transcriptome of two highly divergent genotypes of Urochloa humidicola (Poaceae), a tropical polyploid forage grass adapted to acidic soils and temporary flooding areas. BMC Genomics, 17, 2-19. https://doi.org/10.1186/s12864-016-3270-5

Wricke, G., \& Weber, W. E. (1986). Quantitative genetics and selection in plant breeding. New York, NY: Walter de Gruyter.

Yao, W. H., Zhanga, Y. D., Kangb, M. S., Chena, H. M., Liua, L., Yua, L. J., \& Fan, X. M. (2013). Diallel analysis models: A comparison of certain genetic statistics. Crop Science, 53, 1481-1490. https://doi. org/10.2135/cropsci2013.01.0027
Young, B. A., Sherwood, R. T., \& Bashaw, E. C. (1979). Cleared-pistyl and thick-sectioning techniques for detecting aposporous apomixis in grasses. Canadian Journal of Botany, 57, 1668-1672.

Zorzatto, C., Chiari, L., De Araújo Bitencourt, G., Valle, C. B., Leguizamón, G. O. C., Schuster, I., \& Pagliarini, M. S. (2010). Identification of a molecular marker linked to apomixis in Brachiaria humidicola (Poaceae). Plant Breeding, 129, 734-736. https://doi. org/10.1111/j.1439-0523.2010.01763.x

How to cite this article: de Figueiredo UJ, Barrios SC, Valle CB, Nunes JAR. Combining ability among apomictic and sexual parents of Urochloa humidicola. Grass Forage Sci. 2019;74:678-686. https://doi.org/10.1111/gfs.12444 